\title{
ANALISIS BIAYA RANSUM PENGGUNAAN SERBUK GERGAJI HASIL REKAYASA SEBAGAI PENGANTI SEBAGIAN RANSUM ITIK PETELUR DI DESA TOUNELET KECAMATAN KAKAS KABUPATEN MINAHASA
}

\author{
Viviani .A. Otay*, M. A.V. Manese ${ }^{* *}$, G. D. Lenzun**, P. O.V Waleleng**
}

Fakultas Peternakan, Universitas Sam Ratulangi Manado, 95115

\begin{abstract}
ABSTRAK
Itik merupakan salah satu ternak yang dikembangkan masyarakat untuk sumber pendapatan mereka. Tetapi, pakan itik sering fluktuatif sehingga perlu dicari alternatif untuk bahan ransum itik. Serbuk gergaji sebagai limbah pertanian bermanfaat sebagai pengganti sebagian ransum itik. Permasalahannya adalah sejauh mana biaya yang digunakan terhadap penggunaan ransum serbuk gergaji yang direkayasa sebagai penganti sebagian ransum itik layer lokal di Desa Tounelet Kecamatan Kakas. Tujuan dalam penelitian ini untuk mengetahui biaya ransum yang direkayasa dan tidak direkayasa, dan berapa harga ransum yang paling rendah. Penelitian ini dilaksanakan di Desa Tounelet Kecamatan Kakas Kabupaten Minahasa dengan jumlah ternak itik layer 60 ekor yang mengkonsumsi serbuk gergaji yang direkayasa. Waktu penelitian dan pengumpulan data selama 2 bulan. Data dalam penelitian ini diperoleh dari 2 sumber yaitu data primer dan data sekunder. Hasil dalam penelitian menunjukkan bahwa biaya ransum ternak itik layer yang tinggi terdapat pada ransum dasar R0 sedangkan biaya ransum rendah terdapat pada ransum rekayasa $\mathrm{R} 3$, dan penggunaan ransum rekayasa serbuk gergaji masih lebih menguntungkan dibandingkan dengan penggunaan pakan ransum non rekayasa.
\end{abstract}

Kata Kunci: ransum, serbuk gergaji rekayasa, ternak itik

\footnotetext{
*Alumni Fakultas Peternakan Unsrat

**Jurusan Sosial REkonomi Peternakan
}

\begin{abstract}
ANALYSIS OF FEED COST USING SAWDUST ENGINEERING AS PART IN RATION OF LAYER DUCK AT TOUNELET VILLAGE, KAKAS DISTRICT, MINAHASA REGENCY. Duck was one animal species developed by communities as their source of income at Tounelet village. Animal feed cost was the main problem due to limitation of feed ingredient materials. Sawdust was saw-mill by-product containing high lignin. Lignin could be reduced by engineering method. The objective of this study was to evaluate feed cost using sawdust engineering as part in ration of layer duck at Tounelet village, Kakas district of Minahasa regency. Total oh sixty layer duck was used in this study fed ration containing part of sawdust engineering. Primer and secunder data were collected during two months. Results showed that the highest feed cost of layer duck was found in ration without sawdust engineering. The lowest feed cost was found in ration consisted of 40 percents based ration and 60 percents parts of sawdust engineering. Therefore, it can be concluded that utilization of parts of sawdust engineering was more efficient in layer duck ration.
\end{abstract}

Key words: ration, sawdust engineering, layer duck

\section{PENDAHULUAN}

Peternakan merupakan salah satu sub sektor pertanian yang berperan penting dalam menunjang kebutuhan masyarakat sebagai protein hewani. Usaha ternak itik layer merupakan salah satu usaha 
peternakan yang dapat menyediakan sumber protein hewani dalam bentuk daging dan telur.

Model peternakan itik kebanyakan menggunakan cara tradisional yang skala pemeliharaannya kecil dan model pemberian pakan yang mengandalkan pakan alami (Prasetyo dkk, 2010; Salendu, 2012 dan Elly dkk, 2014). Saat ini berkembang bisnis ternak itik untuk pemenuhan kebutuhan daging dan untuk kebutuhan telur yang sudah ada sebelumnya. Prospek dari usaha pemeliharaan itik petelurpun cukup baik mengingat konsumsi telur dari tahun ke tahun terus meningkat, pemeliharaannya sudah mengarah pada semi intensif maupun kearah intensif (Simamora, 2001; Polakitan dan Paat, 2012).Ternak itik layer mempunyai pertumbuhan yang cepat, konsumsi ransum yang efisien dan biaya produksi yang lebih murah. Itik merupakan ternak yang dapat menghasilkan telur dalam waktu yang cepat serta dapat mengkonversi makanan menjadi daging dan telur secara efisien.

Salah satu faktor yang menentukan efisien tidaknya produksi ternak adalah umlah ransum yang dikonsumsi untuk memproduksi satu kilogram bobot telur yang biasa disebut konversi ransum. Semakin kecil rasionya berarti semakin efisien produksi ternak tersebut. Biaya produksi merupakan biaya terbesar dalam suatu usaha peternakan yaitu sekitar 60 $70 \%$ berasal dari pakan dan selebihnya berasal dari biaya produksi lainnya (Samosir, 1990 dan Arifien, 2002).

Biaya pakan yang tinggi dapat ditekan, tetapi perlu adanya usaha-usaha yang efisien dalam pemanfaatan ransum oleh ternak, supaya peningkatan pendapatan dapat dicapai sesuai yang diharapkan. Serbuk gergaji bisa digunakan sebagai pakan ternak tetapi harus diolah terlebih dahulu (pakan ternak yang direkayasa). Rekayasa pakan dengan memanfaatkan serbuk gergaji tidak memerlukan biaya yang cukup banyak (Rembet, 1996).

Penelitian dilakukan pada usaha ternak itik sebanyak 60 ekor itik layer betina lokal pada awal percobaan berumur 15 bulan. Pemberian ransum percobaan ini menggunakan ransum yang terdiri dari 40 $\%$ jagung kuning, 30\% dedak halus, dan $30 \%$ konsentrat sebagai ransum dasar. Selanjutnya formula ransum dasar ini diganti sebagian dengan serbuk gergaji yang direkayasa dengan tingkat penggunaan $20 \%$ sampai $60 \%$ dalam ransum. Permasalahannya berapa besar biaya yang dikeluarkan apabila menggunakan ransum yang direkayasa untuk beberapa perlakukan dan ransum yang tidak direkayasa. Tujuan dari 
penelitian ini untuk mengetahui biaya ransum yang direkayasa dan tidak direkayasa.

\section{METODE DAN MATERI PENELITIAN}

Penelitian ini dilakukan di Kecamatan Kakas di Desa Tounelet. Data dalam penelitian ini dikumpulkan dengan menggunakan metode survey. Metode survey merupakan suatu teknik pengumpulan informasi yang dilakukan dengan cara menyusun daftar pertanyaan yang diajukan pada ternak itik di Desa Tounelet kecamatan Kakas. Data juga diperoleh dari data olahan hasil penelitian skripsi Jemmy Khusuma yang berjudul : Pengaruh Penggunaan Serbuk Gergaji Yang Direkayasa Melalui Bioteknologi "Efective Microorganims" Sebagai Penganti Sebagian Ransum Itik Layer Lokal Tahun 2002.

Jenis Data yang digunakan dalam penelitian ini yaitu data primer dan sekunder. Data primer (studi kasus) seperti hasil penelitian tentang pakan, tenaga kerja, modal dalam usaha ternak itik dan juga diperoleh melalui informasi dari pasar toko-toko yang menjual ransum (makanan ternak) seperti jagung, dedak halus dan konsentrat. Sedangkan data sekunder diperoleh dari instansi yang terkait seperti peternak itik yang ada di
Kakas dan sekitarnya, Dinas Pertanian dan Peternakan Provinsi dan BPS sulut.

Variabel dan pengukurannya

dalam penelitian ini, diantaranya :

Pakan adalah makanan atau asupan yang diberikan untuk ternak sebagai sumber energi dan sumber gizi (Rp/kg); (2) Serbuk gergaji rekayasa adalah hasil olahan serbuk gergaji rekayasa yang terdiri dari ransum campuran serbuk gergaji $0,5 \mathrm{~kg}$, tepung jagung kualitas jelek $0,5 \mathrm{~kg}$, gula aren $0,005 \mathrm{~kg}$ dan larutan Em4 5 ml (Rp/kg); (3) Ransum adalah pakan jadi yang siap diberikan pada ternak, disusun dari berbagai jenis bahan pakan yang sudah dihitung (dikalkulasi) sebelumnya berdasarkan kebutuhan nutrisi dan energi yang diperlukan ( $\mathrm{Rp} / \mathrm{kg})$; (4) Konsumsi ransum adalah makanan yang diberikan kepada ternak itik sesuai kebutuhan selama 24 jam $(\mathrm{Rp} / \mathrm{kg})$; (5) RO yaitu ransum dengan perbandingan $40 \%$ jagung kuning, $30 \%$ dedak halus, dan 30\% konsentrat sebagai ransum dasar yg diukur dalam satuan $\mathrm{Rp} / \mathrm{kg}$; (6) R1 yaitu perbandingan $80 \%$ ransum dasar selajutnya ransum dasar ini di tambah sebagian dengan serbuk gergaji yang direkayasa dengan tingkat penggunaan $20 \% \quad(\mathrm{Rp} / \mathrm{kg}) ;(7) \mathrm{R} 2$ yaitu perbandingan ransum dasar $60 \%$ selanjutnya ransum dasar ini ditambah sebagian dengan serbuk gergaji yang 
direkayasa dengan tingkat penggunaan 40\% (Rp/kg); (8) R3 yaitu perbandingan pakan Ransum dasar $40 \%$ selajutnya ransum dasar ini ditambah sebagian dengan serbuk gergaji yang direkayasa dengan tingkat penggunaan $60 \%(\mathrm{Rp} / \mathrm{kg})$.

Biaya ransum mencakup $70-80 \%$ dari seluruh pengelolaan peternakan. Harga bahan baku yang kompetitif diharapkan biaya ransum dapat ditekan. Biaya ransum dihitung sebagai berikut :

Biaya pakan $=$ Harga Konsentrat + Harga jagung + Harga Dedak halus + Harga serbuk gergaji.

1. RO (Ransum dasar) : Harga Jagung $(\mathrm{Rp})=40 \% \times$ Harga jagung; Harga Dedak Halus $(\mathrm{Rp})=30 \% \times$ Harga Dedak; Harga Konsentrat $(\mathrm{Rp})=30 \%$ $\times \quad$ Harga Konsentrat; $(\mathrm{R} 1, \mathrm{R} 2, \mathrm{R} 3=$ Ransum dasar + Pakan serbuk gergaji yang direkayasa).

2. $\mathrm{R} 1=80 \% \quad \mathrm{R} 0=\mathrm{Rp}$.

$$
20 \% \text { SGR }=\mathrm{Rp} \text {. }
$$

3. $\mathrm{R} 2=60 \%$ Ro $=\mathrm{Rp}$

$$
\text { . } 40 \% \text { SGR }=\mathrm{Rp} .
$$

4. $\mathrm{R} 3=40 \%$ Ro $=\mathrm{Rp}$.

$$
60 \% \text { SGR }=\text { R.p }
$$

Serbuk gergaji terekayasa diperoleh dari hasil variable cost pembuatan/ pengolahan serbuk gergaji yaitu:

1. Serbuk Gergaji

$$
=0,5 \mathrm{~kg} \times \text { Harga }
$$

SGR

2. Tepung Jagung Kualitas

Jelek $=0,5 \mathrm{Kg} \times$ Harga

Tepung jagung KJ

3. Gula Aren

$$
\begin{gathered}
=0,005 \times \text { Harga Gula } \\
\text { aren }
\end{gathered}
$$

\section{Larutan EM4}

$=5 \mathrm{ml} \times$ Harga Larutan

\section{EM4}

\section{HASIL DAN PEMBAHASAN}

Ransum merupakan faktor produksi utama dalam usaha ternak itik karena mempengaruhi pertumbuhan dan produksi telur. Peternak di desa Tounelet memberikan ransum yang umum dikonsumsi ternak itik yaitu jagung, konsentrat, dedak halus. Peternak juga memberikan ransum serbuk gergaji yang sudah diolah/direkayasa menjadi pakan. Hal ini dilakukan oleh peternak untuk menekan biaya pakan. Harga jagung 3500/kg, sedangkan konsentrat 9500/kg dan pakan serbuk gergaji yang dibuat sendiri tidak membutuhkan biaya banyak. Rataan jumlah konsumsi ransum, bobot telur dan konversi ransum sesuai hasil 
penelitian Khusuma (2002) dapat dilihat pada Tabel 1.

Pemberian ransum satu ekor ternak itik sesuai Tabel 1 menunjukkan pada R0 sebesar 182,37 gram dengan pemberian ransum tersebut bobot telur mencapai 67,9 gram. Perlakuan R1 pemberian ransum
176,69 gram bobot telur mencapai 65,8 gram, R2 konsumsi ransum 172,18 bobot telur mencapai 65,2 gram per butir, R3 konsumsi ransum 189,59 gram bobot telur mencapai 64,4 gram perbutir telur.

Secara teknis tujuan pemeliharaan itik petelur adalah untuk menghasilkan

Tabel 1. Rataan Jumlah konsmsi ransum,bobot telur, dan konversi ransum

\begin{tabular}{lcccc}
\hline \multirow{2}{*}{ Peubah } & \multicolumn{4}{c}{ Perlakuan } \\
\cline { 2 - 5 } & R0 & R1 & R2 & R3 \\
\hline Konsumsi Ransum (Gram) & 182,37 & 176,69 & 172,18 & 189,59 \\
Bobot telur (Gram) & 67,9 & 65,8 & 65,2 & 64,4 \\
Konversi Ransum & 2,69 & 2,69 & 2,64 & 2,94 \\
\hline
\end{tabular}

Khusuma, 2002

telur (Suharno, 2001). Produksi telur yang lebih tinggi dapat diperoleh dengan pemberian ransum sesuai kebutuhan ternak itik. Produksi telur itik di desa Tounelet sangat tergantung pada sistem pemeliharaan dan pemberian pakan. Ternak itik petelur di desa Tounelet mampu memproduksi telur 5-8 butir perhari.

Biaya merupakan pengorbanan yang harus dikeluarkan dalam setiap peristiwa transaksi (Marmiati, 2011). Pakan adalah komponen biaya terbesar yaitu hampir $60-70 \%$ dari biaya produksi. Penyusunan komposisi pakan tanpa memperhitungkan harga akan mempengaruhi kelangsungan usaha karna tidak lagi menguntungkan. Oleh sebab itu, efisiensi adalah kunci untuk keberhasilan suatu usaha. Biaya pakan adalah salah satu faktor yang menunjang suatu usaha dapat berjalan dengan baik sehinga dapat memberi keuntungan. Biaya ransum R0, R1, R2 dan R3 dapat dilihat pada Tabel 2.

Data Tabel 2 menunjukkan bahwa biaya Ransum Ro diperoleh dari 100\% ransum dasar dikali harga ransum (jagung, konsentrat, dedak), maka biaya ransum Rp5.530/kg. R1 diperoleh dari 80\% penggunaan ransum dasar dikali biaya ransum dasar Rp. 5.530 ditambahkan 20\% dikali biaya serbuk gergaji rekayasa maka biaya ransum Rp 4.889 /kg, R2 dari 60\% penggunaan ransum dasar dikali biaya ransum dasar Rp 5.530 ditambahkan 40\% penggunaan serbuk gergaji dikali biaya serbuk gergaji Rp 2.325 maka biaya R2 $4.248 / \mathrm{kg}$. R3 dari $40 \%$ penggunaan ransum dasar dikali biaya ransum dasar Rp 5.530 ditambahkan 60\% penggunaan 
serbuk gergaji dikali biaya serbuk gergaji Rp 2.325 maka biaya ransum Rp 3.607.

Konsumsi merupakan faktor yang sangat berpengaruh pada pertumbuhan ternak itik petelur. Konsumsi itu dipengaruhi oleh suhu, sistem pemberian ransum, kesehatan itik petelur, kualitas ransum serta sifat genetik itik petelur.
Konsumsi sangat berpengaruh pada produksi yang dicapai karena bila nafsu makan rendah akan menyebabkan laju pertumbuhan itik menjadi terhambat dan akhirnya produksi akan menurun. Konsumsi ransum dan biaya ransum dapat dilihat pada Tabel 3 .

Tabel 2. Biaya Ransum R0,R1,R2,R3.

\begin{tabular}{cc}
\hline Uraian & Biaya Ransum $(\mathrm{Rp} / \mathrm{Kg})$. \\
RO & 5.530 \\
R1 & 4.894 \\
R2 & 4.258 \\
R3 & 3.622 \\
\hline
\end{tabular}

Tabel 3. Konsumsi ransum, biaya ransum R0,R1,R2,R3 (Kg) Rp/60 ekor/hari/kg

\begin{tabular}{cccccl}
\hline Uraian & $\begin{array}{c}\text { Konsumsi } \\
\text { Ransum } \\
(\mathrm{Kg})\end{array}$ & $\begin{array}{c}\text { Banyaknya } \\
\text { Ternak itik } \\
(\text { ekor })\end{array}$ & $\begin{array}{c}\text { Biaya } \\
\text { Ransum } \\
(\mathrm{Rp} / \mathrm{Kg})\end{array}$ & $\begin{array}{c}\text { Total biaya } \\
(\mathrm{Rp})\end{array}$ & $\begin{array}{l}\text { Satu } \\
\text { periode/360 } \\
\text { hari }(\mathrm{Rp})\end{array}$ \\
\hline RO & 0.18237 & 60 & 5.530 & 60.510 & 21.783 .600 \\
R1 & 0.17669 & 60 & 4.894 & 51.883 & 18.677 .880 \\
R2 & 0.17218 & 60 & 4.258 & 43.988 & 15.835 .680 \\
R3 & 0.18959 & 60 & 3.622 & 41.201 & 15.038 .365 \\
\hline
\end{tabular}

Data pada Tabel 3 menunjukkan R0 dengan konsumsi ransum $0,18237 \mathrm{~kg}$ untuk 60 ekor ternak itik, totalnya $10.9422 \mathrm{~kg}$, dengan biaya pakan $\mathrm{Rp}$ $5.530 / \mathrm{kg}$ maka total biaya ransum $\mathrm{Rp}$ $60.510,366$ atau $\operatorname{Rp} 22.086 .283,59$ selama setahun. R1 dengan konsumsi ransum $0,17669 \mathrm{~kg}$ untuk 60 ekor ternak itik, totalnya $10.6014 \mathrm{~kg}$, dengan biaya pakan $\mathrm{Rp} 4.889 / \mathrm{kg}$ maka total biaya ransum $\mathrm{Rp} 51.883,245$ atau selama setahun Rp18.658.888,2,- R2 dengan konsumsi ransum 0,17218 $\mathrm{kg}$ untuk 60 ekor ternak itik, totalnya $10.3308 \mathrm{~kg}$,

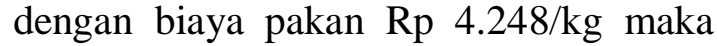
total biaya ransum $\mathrm{Rp} 43.885,238$ atau selama setahun Rp16.018.111,87. R3 dengan konsumsi ransum $0,18959 \mathrm{~kg}$ untuk 60 ekor ternak itik, totalnya $11.3154 \mathrm{~kg}$, biaya pakan $\mathrm{Rp} 3607 / \mathrm{kg}$ maka total biaya ransum $\mathrm{Rp}$ 41.031,068 atau selama setahun Rp14.976.339,82. Data tersebut menunjukkan bahwa biaya pakan yang paling rendah terdapat pada ransum R3 dengan total biaya $R p$ 41.031,068/hari dan selama satu tahun Rp 14.976.339,82 untuk 60 ekor ternak itik. 


\section{KESIMPULAN DAN SARAN}

Berdasarkan hasil penelitian dapat disimpulkan bahwa biaya pakan yang tinggi terdapat pada ransum dasar R0 sedangkan biaya pakan rendah terdapat pada pakan rekayasa R3. Penggunaan pakan rekayasa serbuk gergaji masih lebih menguntungkan dibandingkan dengan penggunaan pakan non rekayasa.

Berdasarkan hasil penelitian dapat disarankan bahwa perlu adanya sosialisasi mengenai pemeliharaan ternak itik dengan menggunakan biaya pakan yang direkayasa yaitu menggunakan serbuk gergaji. Perlu adanya penyuluhan bagi peternak itik untuk membuat pakan serbuk gergaji yang direkayasa.

\section{DAFTAR PUSTAKA}

Arifien, M. 2002. Rahasia Sukses Memelihara Ayam Broiler di Daerah Tropis. Penebar Swadaya, Jakarta.

Elly, F.H., M.A.V. Manese., V.V.J. Panelewen dan D. Polakitan. 2014. Penerapan Ipteks bagi Kelompok Tani Ternak itik di Desa Talikuran Kecamatan remboken Kabupaten Minahasa. Makalah Disampaikan Pada acara Seminar Nasional :"Hasil-Hasil Penelitian dan Pengabdian" Tanggal 27-28
Pebruari 2014 di Universitas

Mahasaraswati Bali.

Khusuma, J. 2002. pengaruh penggunaan serbuk gergaji yang direkayasa melalui bioteknologi "Efective Microorganisms" sebagai penganti sebagian ranum itik layer lokal. Skripsi. Fakultas Peternakan Unsrat. Manado.

Marmiati. 2011. Analisis Keuntungan Usaha Ternak Itik Petelur di Kecamatan Remboken. Skripsi. Fakultas Peternakan. UNSRAT. Manado.

Polakitan, D dan P.C. Paat. 2012. Penampilan Itik Jantan Lokal Yang Diberikan Daun Lantoro (leucaena leucocephala) pada Fase Pertumbuhan. Prosiding Seminar Nasional Peternakan Berkelanjutan. Inovasi Agribisnis Peternakan untuk Ketahanan Pangan. Fakultas Peternakan Universitas Padjajaran, Bandung. Prasetyo, L.H., P.P. Ketaren., A.R. Setioko., A. Suparyanto., E. Juwarini., T. Susanti dan S. Sopiyana. 2010. Panduan Budidaya dan Usaha Ternak Itik. Balai Penelitian Ternak Ciawi, Bogor.

Rembet, B,W. 1996. Karateristik fisiologi daerah (Hermaologis 
ternak yang mengunakan serbuk gergaji "Solid state fermentation" journal Zootek Fakultas Peternakan Vol 5. Unsrat. Manado.

Salendu, A.H.S. Integrasi Ternak ItikPadi Dalam Menunjang Ketahanan Pangan di Sulawesi Utara. Prosiding Seminar Nasional Peternakan Berkelanjutan. Inovasi Agribisnis Peternakan untuk Ketahanan Pangan. Fakultas Peternakan Universitas Padjajaran, Bandung.

Simamora. 2001. Memenngkan Pasar dan Pemasaran Efektif dan Profitabel. PT Gramedia Pustaka Utama. Jakarta.

Suharno, A. 2001. gambaran umum usaha budidaya itik / bebek di Indonesia. http://www.pustakadunia.com 
Tabel 1. Rataan Jumlah konsmsi ransum, bobot telur, dan konversi ransum

\begin{tabular}{lcccc}
\hline \multirow{1}{*}{ Peubah } & \multicolumn{4}{c}{ Perlakuan } \\
\cline { 2 - 5 } & R0 & R1 & R2 & R3 \\
\hline Konsumsi Ransum (Gram) & 182,37 & 176,69 & 172,18 & 189,59 \\
Bobot telur (Gram) & 67,9 & 65,8 & 65,2 & 64,4 \\
Konversi Ransum & 2,69 & 2,69 & 2,64 & 2,94 \\
\hline
\end{tabular}

Khusuma, 2002

Tabel 2. Biaya Ransum R0,R1,R2,R3 .

\begin{tabular}{cc}
\hline Uraian & Biaya Ransum $(\mathrm{Rp} / \mathrm{Kg})$. \\
\hline RO & 5.530 \\
R1 & 4.894 \\
R2 & 4.258 \\
R3 & 3.622 \\
\hline
\end{tabular}

Tabel 3. Konsumsi ransum, biaya ransum $R 0, R 1, R 2, R 3(K g) R p / 60$ ekor/hari/kg

\begin{tabular}{cccccl}
\hline Uraian & $\begin{array}{c}\text { Konsumsi } \\
\text { Ransum } \\
(\mathrm{Kg})\end{array}$ & $\begin{array}{c}\text { Banyaknya } \\
\text { Ternak itik } \\
(\text { ekor })\end{array}$ & $\begin{array}{c}\text { Biaya } \\
\text { Ransum } \\
(\mathrm{Rp} / \mathrm{Kg})\end{array}$ & $\begin{array}{c}\text { Total biaya } \\
(\mathrm{Rp})\end{array}$ & $\begin{array}{l}\text { Satu } \\
\text { periode/360 } \\
\text { hari }(\mathrm{Rp})\end{array}$ \\
\hline RO & 0.18237 & 60 & 5.530 & 60.510 & 21.783 .600 \\
R1 & 0.17669 & 60 & 4.894 & 51.883 & 18.677 .880 \\
R2 & 0.17218 & 60 & 4.258 & 43.988 & 15.835 .680 \\
R3 & 0.18959 & 60 & 3.622 & 41.201 & 15.038 .365 \\
\hline
\end{tabular}

